\title{
Result of Development Investment Road Transport Infrastructure in Vietnam
}

\author{
Bui Manh Hung \\ Hanoi Architectural University (HAU)
}

\begin{abstract}
s
This study was conducted to analyze the current status of investment and development in road transport infrastructure in Vietnam, therefore analyzing the results of investment in road transport infrastructure development in Vietnam. Author analyzed the advantages and disadvantages and base on this to proposing recommendations to further improve the achievements of investment in road infrastructure development in Vietnam.
\end{abstract}

Keywords: Keywords: Road transport infrastructure, investment, traffic, Vietnam

\section{Introduction}

In the context of international economic integration in an increasingly deep and wide as present in countries around the world, investment in road transport infrastructure development is becoming more and more important, contribute to the socio-economic development of each country, improve the competitiveness of countries in the world in attracting investment capital, trading goods ...Convenient transportation will contribute to a good competitive advantage simultaneously saving transportation costs for individuals in the economy.

With the position and role in the national socio-economic development, simultaneously to meet the requirements of the industry, Vietnam transport sector has proposed transport policies and strategies to 2020 and vision to 2030, with constant efforts in implementing the objective of developing transport infrastructure in terms of quantity, besides, it is to improve the quality of transport works throughout the territory. Specifically, the Ministry of Transport has focused on resolving issues such as restructuring, equitization of government-owned enterprises, reform of administrative procedures in order to improve business efficiency, create favorable mechanisms to attract investment flows into the transport sector ...The result of those efforts is a series of key transport projects launched, create a foundation and make a significant contribution to the development of other industries.

According to the statistics of Vietnam Road Administration, in 2016, Vietnam has achieved certain results of investment in developing road transport infrastructure, specifically: about the national highway system: total length of national highways has been completed and come into operation about $309969 \mathrm{~km}$, which the total length of national highways is about $22660 \mathrm{~km}$, the length of provincial roads is about $23729 \mathrm{~km}$, and the length of district roads is about 53964 . kilometer, the length of commune roads to be completed and come into operation about 202705 
Journal of Business School, vol.2, issue.6, pp.21-30

$\mathrm{km}$ and the number of $\mathrm{km}$ of specialized roads completed and come into operation about 6911 km (Vietnam Road Administration, 2017)

However, besides the results of investment in developing road transport infrastructure, there are still limitations such as: there are projects that are still wasted, the time to implement the project delayed...One of the causes of this phenomena is due to the characteristics of investment projects on road transport infrastructure development: The time to implement the projectn is long, depends on natural conditions, long payback period, constructed projects account for a significant proportion of projects, public works ...therefore, the risk of projects is inevitable.

From this reasons, the study of the current situation of road transport infrastructure development, from that analyzing the results of investment in the development of road transport infrastructure, indicating the achievements and limitations as a basis for proposing recommendations to improve the results of investment in road transport infrastructure development are necessary.

\section{Research overview}

Approaching the aspects of State management experience on investment in infrastructure construction in a number of different countries through the use of the State budget, Bernard Myers and Thomas Laursen (2008) summarize the experience of State management on infrastructure construction investment in EU member countries. While some researchers consider investment by the state sector or public investment consider this investment as an input of the production process (Arrow et al., 1970) has shown that public investment plays a role and contributes positively to economic growth, but one of the important items in public investment activities is investment in the transport infrastructure system, researchers have inherited the study of Arrow and his colleagues to continue to develop public investment and among them, the endogenous growth model of Glomm and Ravikumar (1994), Fisher and partner (1998) Gromm et al. (1992) also demonstrated the existence of a single competitive equilibrium represented by the Euler equation and established the existence of an optimal public investment plan.

In 2010, Alfredo M. Pereira et al conducted their research to review of studies related to economic effects of infrastructure investment using investment capital from the State budget. While Glen Weisbrod (2009) when studying the economic impact of public investment in transport has shown that the development of transport will help save production costs, create mobility in economic activity, create jobs, grow for the economy ... Investing in the transport system will have a long-term impact, so it is important to consider the benefits, costs and the optimal level of investment for transport.

Similar to the views of Glen Weisbrod (2009), Susan Handy (2005) in research has indicated the essential requirement of investing in transportation systems, focusing on building highway systems. Susan Handy said that the construction of expressways will contribute to the development of shopping centers, tourism development, help reduce production costs, faster economic growth and increase the aspirations of urban people living in suburban areas live.

In Vietnam, the development of investment in capital construction also has been studied by many researchers. Specifically, Trinh Thi Thuy Hong (2012) in his study, analyzed the theoretical issues related to investment in capital construction, data collected for research are secondary data from official sources published by ministries and sectors as well as annual reports of departments, there are also primary data collected from interviews the officials who work directly at the State management agency related to capital construction investment and expenditures for capital construction in the province of Binh Dinh. 
Different from the approach in terms of State budget expenditures for capital construction activities of Trinh Thi Thuy Hong, research by Ta Van Khoai (2009) approached the perspective of each construction investment project using capital from the State budget. In the study of Tran Van Khoai have similarities with the research of author Tran Van Hong (2002) when the authors analyze the theoretical issues related to capital construction investment.

However, author Ta Van Khoai uses data collected from published sources of ministries and departments with descriptive statistical methods for analysis in research, these data are mainly related to construction investment projects using the government budget. Besides, in 2003, Phan Thanh Mao also used the descriptive statistical method when studying the use of capital construction investment capital using the State budget, the research analyzed issues related to government expenditure

There are similarities with the research of Phan Thanh Mao (2003) about the research object, about research methods, however, Can Quang Tuan (2009) selected Hanoi city as research area. As the previous studies, in this study, Can Quang Tuan gave general theoretical issues about capital construction investment, the effectiveness of capital construction investment, in which the research on development investment capital is carried out in a perspective related to construction investment capital concentrated from the Government budget. Research has analyzed the status of the organization of management of capital construction investment activities, base on this, analyzing the achievement and limitations to propose solutions to improve the efficiency of using construction investment capital using the Government budget.

Trinh Van Vinh (2000) approach in terms of the work of payment and settlement of works, the author has studied and audited the reports on the settlement of the projects invested by the Government capital and the projects designated by contractors. Also research on inspection work and supervision of works and projects using the State budget capital, the author Nguyen Van Binh (2010) inspect and supervise works and projects using the State budget, Nguyen Van Binh (2010) depth research on financial inspection project construction investment using Government capital, The theoretical issues and practical experience in financial inspection activities have been analyzed by the author in the thesis. Selecting the problem of mobilizing capital for investment in road infrastructure construction, Bui Van Khanh (2010) focused on analyzing the conditions to be able to mobilize capital for this activity in Hoa Binh province.

Pham Thi Tuyet (2015) has a different approach when referring to the reality of Vietnam's road transport development in the previous period and proposed the demand for capital in road transport development in the next period (forecast of investment capital demand by 2020), the author also pointed out that the current investment in road transport infrastructure only focuses on three main sources: Foreign loans, Government bonds and mobilized from the Government budget, the results and limitations are also pointed out, from that propose some recommendations to develop the road transport system in Vietnam. Similar to the approach of Pham Thi Tuyet but does not forecast capital demand for road transport infrastructure in the future, Pham Dinh Hanh (2016) uses data of the Ministry of Transport about the status of investment in road transport infrastructure development to analyze aspects and limitations to be able to propose recommendations contribute to further improve the development of investment activity of road transport infrastructure in our country.

There is a relative similarity in the approach to the problem as well as the use of descriptive statistical research and interpretation of research findings with author Pham Thi Tuyet (2015), with data used from the annual summary report of the Ministry of Transport authored Vu Dinh Anh (2016) in this research analyzed the capital demand for investment in transport infrastructure development. Also approaching in the direction of capital sources in the 
transport sector, unlike the author Vu Dinh Anh (2016), author Nguyen Tien Dong (2016) focused on considering bank credit with the delivery field information investment in transport infrastructure is the foundation for rapid and sustainable economic growth, creating a favorable socio-economic environment to attract investment from domestic and foreign economic sectors, contributing to the implementation of the tasks industrialization and modernization of the country

Also selecting the research object is the road transport infrastructure system of Vietnam as previous studies of Vu Dinh Anh (2016), Nguyen Van Vinh (2016), Pham Thi Tuyet (2015), however, the research of Tran Dinh Thien and Phi Vinh Tuong (2016) focus on developing Vietnam transport infrastructure to meet the requirements of industrialization, modernization in the context of international economic integration, the new context has been focused on exploiting this research by the authors. Research has analyzed the successes and limitations in transport infrastructure development in Vietnam; the development of enterprises in the transport infrastructure sector also has been analyzed by the research team. The author also pointed out the development in both quantity and quality of these enterprises in the research period.

\section{Research Methodology}

Data used in the study were collected from the annual summary report of the Vietnam Ministry of Transport. Descriptive statistical methods, comparison methods and interpretation of research findings are used in this study.

\section{Results of investment in road transport infrastructure development in Vietnam}

\subsection{Current situation of investment in road transport infrastructure development in Vietnam}

*) Investment in road transport infrastructure development according to the scale of investment capital

Table 1: Summary of investment capital for road transport infrastructure development in the period of 2015-2017

Unit: billion VND

\begin{tabular}{|l|l|l|l|}
\hline No & $\mathbf{2 0 1 5}$ & $\mathbf{2 0 1 6}$ & $\mathbf{2 0 1 7}$ \\
\hline Capital scale & 86639,9 & 63067 & 72921 \\
\hline State budget & 6494 & 20242 & 31616 \\
\hline Government bonds & 37708,9 & 13144 & 21305 \\
\hline $\begin{array}{l}\text { Extra-budgetary } \\
\text { resources }\end{array}$ & 41980 & 29681 & 20000 \\
\hline
\end{tabular}

Source: Vietnam Road Administration - Ministry of Transport

The scale of investment capital for road transport infrastructure development tends to change positively in the period of 2015-2017, in 2015, the scale of investment capital is about VND 86639.9 billion by 2016, the scale of capital tends to decrease to VND 63067 billion, there is a relative decrease, this is the phase when new projects are starting to deploy, not completed disbursement, therefore, the scale of capital has changed slightly in the direction of reducing. By 2017, the scale of investment capital in road transport infrastructure development tends to increase to 72921 billion VND, new projects are deployed relatively much, the government is giving priority to investment in the development of road transport 
infrastructure, especially in remote areas, the roads linking north and south, therefore, the scale of investment capital increases.

In the total scale of investment capital for developing road transport infrastructure with state budget capital, capital of government bonds and capital outside the state budget, which the proportion of state budget capital accounts for a large proportion with about 31616 billion VND of the total investment capital for developing road transport infrastructure is 72921 billion VND.

Although the scale of investment capital for developing road transport infrastructure in Vietnam in general tends to change uneven, but capital from the state budget for these items tends to increase steadily during the research period, increase over the prior year, this shows the position and role of state budget capital for investment in road transport infrastructure development in Vietnam.

Table 2: Number of investment projects to develop road transport infrastructure using state budget capital

Unit: Project

\begin{tabular}{|l|l|l|l|}
\hline No & $\mathbf{2 0 1 5}$ & $\mathbf{2 0 1 6}$ & $\mathbf{2 0 1 7}$ \\
\hline Number of projects in progress & 115 & 128 & 153 \\
\hline New construction project & 54 & 69 & 87 \\
\hline
\end{tabular}

Source: Vietnam Road Administration - Ministry of Transport

Investment projects to develop road transport infrastructure in Vietnam tend to increase during the research period, including both ongoing projects and new projects, however, there are also have problems with these projects, which project progress slowly than expected, the previous year projects, old projects were stagnant and extended. The disbursement's status not planned because wrong schedule of projects is also a big and urgent issue for investment projects to develop road transport infrastructure using state budget in Vietnam.

*) Regarding investment capital for developing road transport infrastructure according to construction items

Regarding investment capital for National Highway (not including National Highway 1 and Ho Chi Minh Road), investment capital fluctuates VND 255701 billion, an average of VND 31963 billion / year, of which extra-budgetary resources is VND 17023 billion and VND 84222 billion has not been found.

Table 3: Investment capital for upgrading national highways

(Not including Ho Chi Minh Road and Highway 1)

Unit: VND billion

\begin{tabular}{|l|l|l|l|l|}
\hline No & Source & $\mathbf{2 0 1 2 - 2 0 2 0}$ & $\mathbf{2 0 1 2}-\mathbf{2 0 1 5}$ & $\mathbf{2 0 1 6} \mathbf{- 2 0 2 0}$ \\
\hline 1 & ODA & 92956 & 66297 & 26659 \\
\hline 2 & State budget & 16908 & 12711 & 4197 \\
\hline 3 & Government bonds & 44592 & 23850 & 20742 \\
\hline 4 & Off-budget capital & 17023 & 10711 & 6313 \\
\hline 5 & No source & 84222 & 19822 & 64400 \\
\hline & Total & $\mathbf{2 5 5 7 0 1}$ & $\mathbf{1 3 3 3 9 1}$ & $\mathbf{1 2 2 3 1 1}$ \\
\hline
\end{tabular}

Source: Decision No. 355 regulates Vietnam Transportation Development Strategy to 2020, vision to 
Regarding development investment capital for National Highway 1, about VND 89362 billion in the whole period, an average of VND 22340 billion / year, Ho Chi Minh road is about VND 240839 billion, an average of VND 26760 billion / year.

In the period of 2012-2015, the total investment capital for upgrading national highways in Vietnam is about VND 133391 billion, in which the majority of the Government capital is contributed by the State budget capital (about VND 12711 billion), official development assistance (VND 66297 billion) and Government bond capital (VND 23850 billion).

While, it seem to be more difficulties in the period of 2016-2020, with highway upgrading projects, projects without capital account for a relatively large proportion of capital (about VND 64400 billion) while Government capital accounts for a relatively large proportion in this period, official development aid (about VND 26659 billion), Government budget capital is about 4197 billion dong.

For investment capital with the aim of upgrading and expanding national highway 1, Ho Chi Minh Road accounting for a relatively large proportion of capital, which the national highway 1 expansion capital is estimated at VND 89362 billion,which the period 2012-2015 implemented 67022 billion VND, expected capital in the period 2016-2020 is about 22340 billion VND.

For Ho Chi Minh road, the estimated total investment capital is about VND 240839 billion, which the implementation capital for the period of 2012-2015 is about VND 69997 billion, and it is expected that the period of 2016-2020 will be about VND 170842 billion.

The project of renovating, expanding and upgrading national highway 1 and Ho Chi Minh road is a key project in the period of 2012-2020, the capital source for implementing these projects is as follows:

Table 4: Capital for upgrading and expanding national highway 1 and Ho Chi Minh road

Unit: billion

\begin{tabular}{|l|l|l|l|l|}
\hline No & Road name & Total & $\mathbf{2 0 1 2}$ - 2015 & $\mathbf{2 0 1 6 - 2 0 2 0}$ \\
\hline 1 & National Highway 1 & 89362 & 67022 & 22340 \\
\hline 2 & Ho Chi Minh road & 240839 & 69997 & 170842 \\
\hline
\end{tabular}

Source: Decision No. 355 adjusted Vietnam transport development strategy by 2020, vision to 2030

Table 4 shows that the capital for upgrading and expanding national highway 1 in the period of 2012-2015 is about VND 67022 billion, accounting for about 2/3 of the total capital of the project. While, the capital to upgrade Ho Chi Minh road is about VND 69997 billion in the period of 2012-2015 and is expected to supplement about VND 170842 billion for the period 2016-2020.

About the investment capital for expressway system development, about VND 4,46289,669 billion, an average of VND 49092 billion / year, which the North-South Expressway in the East, about VND 209173 billion, an average of VND 26147 billion / year. 
Journal of Business School, vol.2, issue.6, pp.21-30

Table 5: Investment capital for highway development

\begin{tabular}{|l|l|l|l|}
\hline No & Items & $\begin{array}{l}\text { Length } \\
(\mathrm{Km})\end{array}$ & $\begin{array}{l}\text { Value } \\
\text { (Billions dong) }\end{array}$ \\
\hline A & Completed projects (5 routes) & $\mathbf{1 6 7}$ & \\
\hline B & Completed projects in the period of 2013 - 2020 & $\mathbf{1 8 5 1 , 6}$ & $\mathbf{4 4 6 2 8 9 , 6 6 9}$ \\
\hline 1 & North - South Expressway (10 routes) & 776 & 209172,796 \\
\hline 2 & Northern Expressway (6 routes) & 705 & 123660 \\
\hline 3 & Southern Expressway (1 route) & 76 & 13802 \\
\hline 4 & Hanoi Belt Road, Ho Chi Minh City (3 routes) & 94,6 & 45744,331 \\
\hline 5 & Other highways & 200 & 53910,541 \\
\hline & Total & $\mathbf{2 0 1 8 , 6}$ & \\
\hline
\end{tabular}

Source: Decision No. 355 regulates Vietnam Transportation Development Strategy to 2020, vision to 2030

Development investment capital for coastal road system is about 28132 billion VND (in the period to 2020 is 16013 billion VND; the period after 2020 is 12120 billion VND); the average period to 2020 is VND 1,600 billion / year. While, the investment capital to develop the provincial road system is about VND 1,200 billion, an average of VND 12,000 billion / year, the urban road traffic for Hanoi capital and Ho Chi Minh City is about VND 287500 billion, the average VND 29,000 billion / year.

\subsection{Results of investment in road transport infrastructure development in Vietnam}

\section{a. The results of the road length system}

According to the Vietnam Road Administration, by the end of 2017, Vietnam has achieved results on investment activities of road transport infrastructure development, specifically:

Table 6: Results of investment in road transport infrastructure development in Vietnam

\begin{tabular}{|c|c|c|}
\hline Items & Unit & $\begin{array}{l}\text { Achieved } \\
\text { Results }\end{array}$ \\
\hline \multicolumn{3}{|l|}{ 1. On the highway system } \\
\hline - Total length of Highway & $\mathrm{Km}$ & 22783 \\
\hline - Total length of provincial roads & $\mathrm{Km}$ & 27176 \\
\hline - Total length of district roads & $\mathrm{Km}$ & 57294 \\
\hline - Total length of commune roads & $\mathrm{Km}$ & 173294 \\
\hline - Total length of specialized roads & $\mathrm{Km}$ & 8528 \\
\hline \multicolumn{3}{|l|}{ 2. On the expressway system } \\
\hline - Total length of expressway is being exploited & $\mathrm{m}$ & 114146,015 \\
\hline - Total length of bridge on expressway & $\mathrm{m}$ & 56563,231 \\
\hline \multicolumn{3}{|l|}{ 3. On the road bridge system } \\
\hline - Total length of the bridge on the highway & $\mathrm{M}$ & 395102 \\
\hline - Total length of bridges on provincial roads & $\mathrm{M}$ & 216625 \\
\hline
\end{tabular}

Source: Vietnam Road Administration

With the highway system by the end of 2017, it has operated about $170709 \mathrm{~m}$, which the total length of expressways is being exploited about 114146,015 $\mathrm{m}$ and about 56563,231 $\mathrm{m}$ of bridges on the highway. 
Journal of Business School, vol.2, issue.6, pp.21-30

\section{b. Achieved results on freight transport}

Table 7: Achieved results on freight transport

\begin{tabular}{|l|l|l|l|l|}
\hline Items & Unit & $\mathbf{2 0 1 5}$ & $\mathbf{2 0 1 6}$ & $\mathbf{2 0 1 7}$ \\
\hline 1. Freight transportation & Triệu tấn & 1134 & 2496,321 & 2675,23 \\
\hline 2. Passenger transportation & Triệu lượt & 3283 & 3017,619 & 3325,18 \\
\hline
\end{tabular}

Source: Vietnam Road Administration

Transportation output in 2015 reached about 1134 million tons, 3283 million passengers; $6 \%$ increase in tons of transport and 7.7\% increase in passenger transport compared to 2014; Increase $58.6 \%$ in freight transportation and $33.4 \%$ in passenger transportation compared to 2010.

Freight transportation output in 2016 increased by 120.13\%, in particular, in 2016, the number of Freight transportation was about 2496.321 million tons compared to 1134 million tons in 2015; The number of passenger transport tends to decrease slightly, in 2016 the number of passenger transport is about 3017,619 million times, this figure in 2015 is about 3283 million (reducing 265,381 million passengers transported).

\section{Recommendations}

To improve the results of investment and development of road transport infrastructure, some recommendations are published as follows: Choosing right investment projects to develop road transport infrastructure: Prioriting to investment in key areas in order to promote economic growth and development of localities.

Building and training staff to work directly related to investment and development of road transport infrastructure from project construction to project disbursement ...

Increasing the level of specialization and concurrent reduction of State management officials in order to get good experts, taking good roles and responsibilities in State management for investment projects on road transport infrastructure development.

Using and effectively mobilizing investment capital for developing road transport infrastructure to contribute effectively to improving the quality of investment and development of road traffic infrastructure, contributing to reducing the capital pressure for the State budget for investment in developing road transport infrastructure, thus contributing to national socioeconomic development.

\section{References}

Alfredo M Pereira, Jorge M Andraz (2010), “On the effects of highway investment on the regional concentration of economic activity in the USA", College of William and Mary department of Economics, Working paper number 107

Alfredo Marvao Pereira, Jorge M. Andraz (2010), “On the economic effects of public infrastructure investment: A survey of the international evidence", college of William and Mary department of economics, working paper 108, December 2010

Arrow, K. J., \& Lind, R. C. (1970), “Uncertainty and the evaluation of public investment decisions", American Economic Review, 50

Bernard Myers và Thomas Laursen (2008), "Public investment management in the new EU 
member States", the World Bank working paper series

Bui Van Khanh (2010), Mobilizing financial resources to build road transport infrastructure in Hoa Binh province, Economic doctoral dissertation, Financial Academy

Can Quang Tuan (2009), some solutions to improve the efficiency of using capital investment in construction focused from the State budget managed by Hanoi City, Doctoral Dissertation, Financial Academy

Glen Weisbrod (2009), Economic impact of public transportation investment, American public transportation association.

Glomm \& Ravikumar (1992), "Public versus private investment in human capital: endogenous growth and income inequality", Journal of Political Economy, 100

Glomm \& Ravikumar (1994), "Public investment in infrastructure in a simple growth model", Journal of Economic Dynamics and Control, 18

Nguyen Tien Dong (2016), "Bank credit capital for the transport sector", Proceedings of the workshop on traffic, Ministry of Transport

Nguyen Van Binh, (2010), improving the efficiency and effectiveness of financial inspection of construction investment projects using Government capital in Vietnam, Doctoral dissertation, Academy of Finance

Pham Dinh Hanh (2016), "Investment in transport infrastructure development: Current situation and solutions", Communist Journal, April issue

Pham Thi Tuyet (2015), "Current situation and demand for capital Vietnam road traffic development ", Journal of transport

Phan Thanh Mao (2003), Financial solution to improve the efficiency of capital construction investment from the State Budget in Nghe An province, Doctoral dissertation, National Economics University

Susan Handy (2005), "Smart growth and the transportation- land use connection: what does the research tell us?",Sage publications, vol 28, No2

Ta Van Khoai (2009), Government Administration for construction investment projects from the State budget in Vietnam, Doctoral dissertation, Ho Chi Minh National Academy of Politics and Public Administration.

Vietnam Road Administration (2014), 2014 statistical information on road traffic

Vietnam Road Administration (2015), 2015 Statistical Information on Road Traffic

Vietnam Road Administration (2016), 2016 Statistical Information on road traffic

Tran Dinh Thien and Phi Vinh Tuong (2016), "Developing Vietnam transport infrastructure to meet the requirements of industrialization and modernization in the context of international economic integration", Proceedings of the workshop on traffic, Ministry of Transport

Tran Van Hong (2002), Renovating the management mechanism using basic construction investment capital of the Government, doctoral dissertation, Academy of Finance.

Trinh Thi Thuy Hong (2012), Managing Government expenditure in construction investment capital in Binh Dinh province, Economic doctoral dissertation, National Economics University 
Journal of Business School, vol.2, issue.6, pp.21-30

Trinh Van Vinh (2000), Audit method of project settlement report in construction works, Economic doctoral dissertation, Hanoi University of Finance and Accountancy

Vu Dinh Anh (2016), "Demand for investment capital for transport infrastructure development", Proceedings of the workshop on traffic, Ministry of Transport. 